\title{
The Development Of Character Achievement Test For Islamic University Students
}

\author{
Ahmad Muhammad Diponegoro' ${ }^{1 *}$, Yuzarion $^{2}$, Widiarti ${ }^{3}$ \\ 1,2,3Ahmad Dahlan University, Yogyakarta, Indonesia \\ 1*ahmad.diponegoro@psy.vad.ac.id, 2yuzarion@psy.vad.ac.id, \\ 3widiarti2008044035@webmail.vad.ac.id,
}

\begin{tabular}{l}
\hline Article Info \\
\hline Article history \\
Received October 11, 2021 \\
Revised December 10, 2021 \\
Accepted December 13, 2021 \\
\hline
\end{tabular}

Keywords: Cognitive domain, taxonomy Bloom, Muslim character, test development.

\begin{abstract}
In this study, we aim to develop an instrument that has never been developed before, the statistically good character test. The instrument can be used to measure the character of Muslim students at the level of competence in knowledge, comprehension, and application. The test development applies a modified 4D model procedure into three stages, define, design, and develop. The reliability of the test was obtained based on the level of reliability, the level of difficulty of the questions, the discriminatory power, and the effectiveness of alternative distractors. The research was conducted in 2021 with a total of 50 students. The results of the study (1) reliability coefficient (a) 0.938 , (2) the average item difficulty level (p) 0.643, (3) the average discriminatory power index (rpbis) was 0.522, (4) the alternative distractors were categorized as effective (50\%) and ineffective (50\%). Based on these findings, it shows that cognitive test devices are feasible to use and can be used to determine the character of Muslim students.
\end{abstract}

\section{INTRODUCTION}

The concept of character education in Islam certainly comes from the primary sources of Islam itself, namely the Qur'an and Hadith. The importance of good character in education has recently been emphasized in both the scientific and popular literature (e.g., Difficult, 2012; Linkins et al., 2015), and researchers from neighboring disciplines (e.g., Hokanson and Karlson, 2013) also call for studying the role of character strengths in education (Wagner \& Ruch, 2015). "Character is destiny." This sentence, attributed to the philosopher Heraclitus of Ephesus (544$484 \mathrm{BC}$ ), has been part of popular wisdom for many years. The character of the Islamic tradition is one of the best things Allah has given Muslims.

The exemplary importance of character demonstrated by thousands of years that the idea of "character" has triumphed holds in human history. This concept - related to education in virtue, the cornerstone of positive psychology (called strength of character - which contains good character) - is re-emerging in the field of Educational Psychology as well as in positive psychology research and practice in the United States, and is beginning to spread to other countries. Except for Muslim countries, which have become a tradition of prioritizing or emphasizing good morals in everyday life. For example, in Indonesia, Malaysia, Turkey, or Saudi Arabia(Chang, 2010). They formally teach character traits both at school and in college. 
Character material for Muslim students is obtained from their religious sources, namely the Qur'an and Hadith(Abu-Raiya, 2015). Both show that the mission of the Prophet Muhammad was to perfect noble character, where the origin of the term "character education" which in Islam has the value of "noble moral education."

Character is a second nature, forged voluntarily by the individual himself, making it possible to live a good life for those around (Lickona, 1999) and a decline in the classic notion of "Character Education." (Vargas \& González-Torres, 2009). Therefore, studying the influence of non-intellectual aspects (e.g., good character) on educational outcomes has a long tradition. Also, specifically the study of good character or positive personality traits has been dealt with by early educational psychologists (e.g., Smith, 1967), but was then ignored for an extended period. Only with the advent of positive psychology has it received a revived interest. Inherent in positive education is the idea that good character, positive behavior in school, and academic achievement are educational goals and are closely related.

The importance of good character in education has recently been emphasized in both the scientific and popular literature (e.g., Difficult, 2012; Linkins et al., 2015), and researchers from neighboring disciplines (e.g., Hokanson and Karlson, 2013) also calls for studying the role of character strengths in education. (Wagner \& Ruch, 2015). Strength of character is expressed in thoughts and feelings and, most importantly, in behavior. Peterson and Seligman, 2004). We expect that several forces are helpful for schoolwork and human relations and thus are closely related to positive behavior in the classroom, as the teachers can observe. Positive behavior in the classroom, for example, being active in class or showing motivation to learn, should ultimately contribute to school achievement. High scores in good character do not automatically and directly lead to high school achievement. However, they will influence students to exhibit a more closely related set of behaviors, affecting higher grades later in life.

From the perspective of Positive Psychology, which focuses on the development of positive youth (Park 2004), we expect that good character (as a contributing factor to good and flourishing life) will serve as a critical resource in the school context, for (1) positive subjective experiences. (e.g., satisfaction with school, academic self-efficacy), for (2) positive behavior in the classroom, and as a consequence of the latter also for (3) objective school success (i.e., grades). The concept of a morally worthy personality in the school context has been neglected since personality psychology discarded the term character (De Raad and Schouwenburg 1996). However, previous literature indicated that morality and character are essential in school. In the early 20th century, character traits (e.g., persistence, attention to detail) contributed to school success (Poffenberger and Carpenter 1924). Decades later, a factor called character strength (consisting of variables such as self-confidence, responsibility, orderliness, social maturity, and resourcefulness) is positively related to academic success (Smith 1967) (Weber \& Ruch, 2012).

Peterson and Seligman (2004) stated that the classification allows a comprehensive

IJEMI Vol.3, No.1, January 2022, pp. 45 58 
study of good character and its contribution to positive development. The VIA classification describes 24 strengths of character, which are organized into six, more abstract virtues (wisdom and knowledge, courage, humanity, justice, temperance, and transcendence). It is seen as a way to achieve these virtues. Strengths of character are seen as inherently valuable, but they also contribute to positive outcomes (Peterson and Seligman, 2004). Strength of character can be seen as a component of good character and is described as a determinant in a good life, complemented by external factors (such as safety, education, and health (Peterson, 2006; Wagner \& Ruch, 2015).

The construction of valid and reliable tests in moral character education subjects has not received sufficient attention in many countries and universities or schools in Indonesia. Schools are expected to have sufficient valid and reliable tests to assess their students when they have covered areas of curriculum content and prepare them for external examinations. It has been observed that most of the teachers are not good at constructing tests in their various subjects (Osadebe, 2001; 2012). As a result of this problem, the researcher built a valid and reliable multiple-choice Moral Character Achievement Test in universities. The built test will be an outstanding contribution to the need for a valid and reliable Character Achievement Test in Islamic universities. During construction tests, many teachers simply hastily copied questions from the previous question paper to compose their summative achievement test. As a result, the teacher did not assign validity and reliability to the test.

Similarly, Onunkwo's (1998) observation that most examiners find it easier to construct test items at lower cognitive levels (knowledge and understanding) than at higher cognitive levels (application, analysis, synthesis, and evaluation) indicates the fact that most of these examiners who are teachers in junior and senior high schools have constructed tests that are not very valid as a problem. However, the construction of test items is an art that few people seem to master (Nunnally, 1981; Osadebe, 2001). Therefore, experts need to build tests that are sufficiently valid and reliable for use in universities. Poorly prepared Achievement Tests often judge them. Their exam content area in Economics is not spread out to cover the content of the Economics curriculum. As a result, the test limits the scope of students' reading, leading to poor performance in Economics. Use of a valid and reliable Economic Achievement Test to assess it.

In Indonesia, students are expected to study Economics as a high school subject for three years or have studied the SSCE Economics curriculum before being assessed with the Economic Achievement Test. The Economic Achievement Test built in this study is a multiplechoice Economic Achievement Test. Multiple-choice items can measure both the level of knowledge and understanding (Gronlund, 1976; Osadebe, 2001). In addition, multiple-choice has the advantage of covering a broad Economics curriculum content and measuring different cognitive outcomes (Knowledge, Understanding, Application, Analysis, Synthesis, and Evaluation). Therefore, as a result of teachers' use of unreliable achievement tests that are 
poorly designed,

In Indonesia, students are expected to study Economics as a high school subject for three years or have studied the SSCE Economics curriculum before being assessed with the Economic Achievement Test. The Economic Achievement Test built in this study is a multiplechoice Economic Achievement Test. Multiple-choice items can measure both the level of knowledge and understanding (Gronlund, 1976; Osadebe, 2001). In addition, multiple-choice has the advantage of covering a broad Economics curriculum content and measuring different cognitive outcomes (Knowledge, Comprehension, Application, Analysis, Synthesis, and Evaluation). Therefore, due to unreliable achievement tests that teachers poorly designed and the need to provide more valid and reliable achievement tests in senior secondary schools, the researcher conceived the idea of creating one to assess students in SS.

\section{METHODS}

This research is a quantitative study using a cognitive scale, namely an achievement test. The data obtained is processed using iteman software. This research is developmental (Research and Development), namely the development of cognitive Taxonomy-based tests (Bloom) on material with a 4-D development model (Define, Design, Develop, Disseminate) from (Lawhon, 1976) modified and adapted into 3-P (Defining, Designing, Developing, Deployment).

The following steps were considered by researchers in constructing and validating achievement tests of moral character knowledge for Muslim university students: Test Planning Before going any further towards constructing achievement tests, it is essential to plan the tests carefully. Test planning includes the following steps: designing achievement tests, test objectives, test content, test item nature, test scoring criteria, so on. Develop a Question Bank from the Content of the Unit of Concern After deciding the purpose of preparing for the achievement test, the content areas for the test items, which the test is for, where and when to take it. The next step is to develop a question bank while still paying attention to specific learning objectives (knowledge, understanding, and application).

\subsection{Definition}

The research begins by identifying the problems in students by analyzing student morals through daily activities as Muslim students. In this case, the researcher determines the moral material to be taken, namely morals to Allah SWT, morals to the Prophet Muhammad, morals to fellow humans, morals to the environment, and morals to the State.

\subsection{Design}

The activity carried out at this stage is the preparation of the initial blueprint by determining the expected reliability value (RTT) of 0.8 and the average discrepancy index (rit) of 0.4 based on the Spearman-Brown formula. With the calculation of the formula that has 
been done, the number of questions that must be compiled is 21 items. Then the researcher multiplied the results of the calculation of the problem into 42 items.

The type of test questions developed/designed in multiple-choice with four alternative answers made according to the tested material. This test is modified from various sources and adapted to the cognitive Taxonomy (Bloom) aspect, which pays attention to the components of knowledge, comprehension, and application.

\subsection{Development}

This stage aims to produce test kits based on 5 test materials. The results of the revised questions that were developed were then tested to determine the level of reliability, level of difficulty, discriminatory power, and effectiveness of alternative distractors. The questions were tested on 36 items with an rpbis value $>0.25$ and 6 items $<0.25$.

\subsection{Subject}

The number of research subjects was 50 students from one of Sumatra's Islamic universities. $10 \%$ of Muslim students and $90 \%$ Muslim women with active status as students.

\subsection{Reliability Analysis}

The reliability in this study is seen from the results of the ITEMAN analysis version 4.3 in the $\mathrm{K}-\mathrm{R} 20$ value table. The measuring instrument is reliable when it meets the minimum Cronbach alpha score of 0.6 (Sugiyono, 2014). This study's measurement of reliability using the Cronbach alpha technique with the reliability coefficient $(r \times x)$ in the range of 0 to 1.00 . The higher the number approaching 1.00, the more reliable the measurement (Azwar, 2012).

\subsection{Difficulty Analysis}

The average value of the difficulty level is seen from the Mean P on the ITEMAN analysis version 4.3. According to Allen and Yen(in Azwar, 2017), the level of difficulty of a good item is 0.3 to 0.7 . Items with a difficulty level below 0.3 are considered difficult items, while if the index is above 0.7 , the items are considered easy. Thus the criteria for the level of difficulty (P) can be written as follows:

$0.00-0.30=>$ the question is classified as difficult

$0.31-0.70=>$ the question is classified as moderate

$0.71-1.00=>$ the question is quite easy

\subsection{Distinguishing Power Analysis}

The average value of discriminating power is obtained from the Mean Rpbis value obtained from the ITEMAN analysis version 4.3, where the item must have an rpbis value $>0.25$.

\subsection{Alternative Effectiveness Analysis}

The distractor is said to function effectively if $5 \%$ of students choose or more of the lower group chooses (Sukiman, 2012). The answer choices consist of a key and a distractor. The answer key must be the correct or most correct answer while the distractor is the incorrect answer, but the distracting power must function, meaning that students may choose it if they do not master the material (Depdikbud, 2005). 


\section{RESULTS AND DISCUSSION \\ RESULTS}

The results of the development research obtained are cognitive tests based on cognitive Taxonomy (Bloom), based on four stages (define, design, develop, disseminate) from Thiagarajan et al. (1974), which was later adapted into the 4Ps (definition, design, development, and deployment). This cognitive test aims to determine the knowledge of moral science material in Muslim students at the level of knowledge, comprehension, and application competence based on the level of reliability, level of problem difficulty, discriminatory power, and the effectiveness of alternative distractors in the knowledge of moral science of Muslim students. Based on the research objectives and the research flow, the researchers have obtained the results of the research that has been carried out, namely:

\subsection{Initial Draft Products}

Conduct the preparation of test kits based on the competency level of knowledge, comprehension, application, and five materials tested, namely Morals to Allah, Morals to the Prophet, Morals to Fellow Humans, Morals to the Environment, and Morals to the State.

\subsection{Results of reliability analysis}

The results of the ITEMAN analysis version 4.3 show reliability of 0.938 . According to Sugiyono(2014), The measuring instrument is reliable when it meets the minimum Cronbach alpha score of 0.6 . according to Azwar (2012), The reliability coefficient $(r \times x)$ is in the range of 0 to 1.00. The higher it is close to 1.00, the more reliable the measurement is.

\subsection{Difficulty Level}

The average item difficulty value was obtained from the Mean P-value obtained from the ITEMAN analysis version 4.3. The result of the difficulty level obtained is 0.643 . According to Allen and Yen (Azwar 2012), the level of difficulty of a good item is 0.3 to 0.7. Items with a difficulty level below 0.3 are considered difficult items, while if the index is above 0.7 , the items are considered easy. The moral cognitive test of Muslim students can be said to have a good level of item difficulty.

\subsection{Distinguishing Power Analysis}

The average value of discriminating power is obtained from the Mean Rpbis value obtained from the ITEMAN analysis version 4.3. The differentiating power obtained from the analysis of cognitive tests is 0.522 by removing six items with an rpbis value of $<0.25$, namely numbers $15,16,22,27,29,38$. The distinguishing power of Muslim students' moral cognitive tests can be categorized as good.

\subsection{The Results of the Distractor Effectiveness Analysis}

The distractor answer choice is practical if it is chosen by $5 \%$ of the test takers or the lower group. The effectiveness of the distractor was carried out to calculate the test takers who chose alternative answers for each item. An answer choice (detractor) can function if the distractor is chosen by at least $5 \%$ of the test takers and is chosen more by groups of students 
who do not understand the material (Depdikbud, 2005). The results of the distractor analysis or distractor answers obtained 36 cognitive test questions; there were 18 items (50\%) having distractors that functioned well, while the other 18 items (50\%) had terrible distractors. Thus, the moral cognitive test of Muslim students can be said to have excellent and lousy distractor effectiveness of $50 \%$ each.

Table 1. Recap of Analysis Results

\begin{tabular}{|c|c|c|c|c|c|}
\hline \multirow{3}{*}{$\begin{array}{l}\text { Test } \\
\text { material } \\
\text { Morals to } \\
\text { Allah }\end{array}$} & \multicolumn{2}{|c|}{$\begin{array}{l}\text { Competency level } \\
\text { No item }\end{array}$} & \multirow{2}{*}{$\begin{array}{l}\begin{array}{l}\text { Different } \\
\text { Power Index }\end{array} \\
\text { Well }\end{array}$} & \multirow{2}{*}{$\begin{array}{l}\text { Question } \\
\text { Difficulty Level } \\
\text { Easy }\end{array}$} & $\begin{array}{l}\text { Effectiveness } \\
\text { distractor }\end{array}$ \\
\hline & Knowledge & 01 & & & Not good \\
\hline & & 02 & Well & Easy & Well \\
\hline & & 03 & Well & Easy & Not good \\
\hline & & 04 & Well & Easy & Not good \\
\hline & Comprehension & 05 & Well & Currently & Well \\
\hline & & 06 & Well & Easy & Well \\
\hline & & 07 & Well & Currently & Well \\
\hline & & 08 & Currently & Easy & Not good \\
\hline & Application & 09 & Well & Easy & Not good \\
\hline & & 10 & Well & Currently & Well \\
\hline & & 11 & Well & Currently & Well \\
\hline & & 12 & Currently & Very easy & Not good \\
\hline \multirow{5}{*}{$\begin{array}{l}\text { Morals to } \\
\text { the Prophet }\end{array}$} & Knowledge & 13 & Well & Easy & Well \\
\hline & & 14 & Well & Easy & Well \\
\hline & Comprehension & 15 & Well & Currently & Well \\
\hline & & 16 & Pretty good & Very easy & Not good \\
\hline & & 17 & Well & Currently & Not good \\
\hline \multirow{7}{*}{$\begin{array}{l}\text { Morals to } \\
\text { Humans }\end{array}$} & Knowledge & 18 & Well & Hard & Well \\
\hline & & 19 & Well & Easy & Not good \\
\hline & & 20 & Currently & Easy & Not good \\
\hline & Comprehension & 21 & Well & Currently & Well \\
\hline & Application & 22 & Currently & Easy & Not good \\
\hline & & 23 & Currently & Easy & Well \\
\hline & & 24 & Well & Currently & Well \\
\hline \multirow{12}{*}{$\begin{array}{l}\text { Morals to } \\
\text { the } \\
\text { Environment } \\
\text { Morals to } \\
\text { the State }\end{array}$} & Knowledge & 25 & Currently & Easy & Not good \\
\hline & & 26 & Well & Easy & Not good \\
\hline & & 27 & Well & Currently & Well \\
\hline & Knowledge & 28 & Well & Currently & Well \\
\hline & & 29 & Well & Currently & Not good \\
\hline & & 30 & Well & Easy & Not good \\
\hline & & 31 & Well & Easy & Not good \\
\hline & & 32 & Well & Currently & Well \\
\hline & Comprehension & 33 & Well & Easy & Well \\
\hline & & 34 & Well & Easy & Well \\
\hline & Application & 35 & Currently & Easy & Not good \\
\hline & & 36 & Currently & Very easy & Not good \\
\hline
\end{tabular}

Based on Table 1, the effectiveness of the distractor was carried out to calculate the test takers who chose alternative answers for each item. An answer choice (detractor) can be said to work if the distractor is chosen by at least $5 \%$ of the test takers and more are chosen by groups of students who do not understand the material (Depdikbud, 2005). The results of the distractor analysis or distractor answers obtained 36 cognitive test questions; there were 18 
items (50\%) having distractors that functioned well, while the other 18 items (50\%) had terrible distractors. Thus, the moral cognitive test of Muslim students can be said to have excellent and lousy distractor effectiveness of $50 \%$ each.

\section{DISCUSSION}

Cognitive tests that have been developed are included in the reliable category with a value of (a) 0.938 indicates that this moral science knowledge test kit is adequate to collect data. The empirical test cognitive test that has been developed has the following qualities: Difficulty Level; based on the results of the analysis obtained by 0.643 , the level of difficulty of the items is good. Distinguishing power; based on the results of the discriminatory analysis obtained by 0.522 , it shows a good category by removing six items with an rpbis value of < 0.25 , namely numbers $15,16,22,27,29,38$. The Effectiveness of Distracting Alternatives; based on the results of the analysis obtained each of $50 \%$. Eighteen items $(50 \%)$ have distractors that function well, while the other 18 have distractors that are not good.

Of the six questions that fell, the questions were quite tricky because they asked for verses and letters in the Qur'an, which were located after Surah Al Baqarah. Usually, the students have not memorized the long letters after al-Baqarah. There are questions about beauty that are currently still being discussed in psychology. Then the question also mentioned the story of the Juraid who did not want to fulfill his mother's call when he was praying sunnah; this behavior made the juraid afflicted with misfortune. If the juraid understands religion, he will cancel his sunnah prayer and fulfill his mother's call. The questions on the front are mostly related to the definition of character material, such as the question of good character, which is commendable.

Cognitive developmental tests or achievement tests are generally developed in schools, universities, or educational institutions. Math and language (Montiel et al., 2019), chemical (Harcourt, 2019), physics (Balta \& Eryllmaz, 2020), and biology (Shahzad Ahmad et al., 2020) is a subject that is often discussed in the development of achievement tests or cognitive tests (Lekwa et al., 2018; Scherrer et al., 2020). Unfortunately, none of the achievement tests relate to moral character.

When a comprehensive approach to character education is used, a positive moral culture is created-a total school environment that supports the values taught in the classroom (Character Education Partnership, 2010)—developed through character education(Ano et al., 2017). This research aims to provide guidelines for the elements of character education needs that are effective and comprehensive as to emphasize the need for character education to help students develop good character, which includes knowing, caring, and acting on core ethical values such as respect, responsibility, honesty, fairness, and compassion. Certain countries in the world teach character formally in schools. The countries that consider religious teachings essential, such as Indonesia, Malaysia (Chang, 2010), Turkey (Adams, 2011), 
and Saudi Arabia. In addition to teaching character, they also develop a character test tool to determine the ability of students or students to understand the principles of good morals or noble character and despicable morals. Islamic schools and Islamic colleges generally also teach character to their students. In Indonesia, for example, Islamic boarding schools or institutions have subjects or subjects called morals.

Character education is a direct approach to moral education, namely, teaching individuals with basic moral knowledge to prevent immoral acts and harm to others or themselves (Santrock, 2011). Character education is not new in the Islamic education system because the spirit or core of Islamic education is character education, initially known as moral education. Islamic education has existed since Islam began to preach the Prophet Muhammad to his companions. Along with the spread of Islam, character education has never been neglected because the Islam spread by the Prophet was Islam in the complete sense, namely integrity in faith, good deeds, and noble character. From this, it can be understood that a devout Muslim is a Muslim who has a strong faith, then practices all the commands of Allah and stays away from all His prohibitions, and finally has a noble attitude and behavior as a consequence of his faith and good deeds (Marzuki, 2015).

Character education in schools is the responsibility of religious teachers or teachers of specific subjects and all teachers and school administrators. Through science and mathematics subjects, honesty, discipline, hard work, independence, curiosity, cooperation, creativity, and responsibility can be developed. According to Hidayat's research (Hidayat et al., 2018), three factors of character strength are formed, namely creativity, curiosity, and love of reading. These three factors can build the value of the virtue of knowledge and wisdom. Character education requires strengthening internal dispositions or facilitation (habits) for good deeds traits of virtue and serve as a growth spiral. According to Aristotle, public support is essential to this process because although one's natural constitution is to live the virtues, it will be avoided if - as is often the case - involves pain or suffering ( $N a v a l, 2001$ ). According to Islam, goodness is what is good according to Allah and the Messenger. Of course, this is different from the meaning of goodness in the west.

For this reason, a character theory was developed by the Qur'an and Hadith. A character learning achievement test is developed to find students' understanding of the theory of good morals according to Islam. A structured test with multiple choice answers and assessed by both theorists and practitioners. With the teacher's help, students learn to know, love, and practice good deeds.

In fostering student morals, school facilities support student moral development activities; students who do good things need to be given rewards or awards so that students are always motivated. In addition to these things, there are also inhibiting factors in the activity, namely the limited supervision of the school, the family environment, the background of less supportive students, and the community environment (Ultra et al., 2020). The teacher's strategy in fostering 
the noble character of students is to carry out activities of habituation, for example, giving advice, providing motivation, prohibition, supervision, and punishment. Which is less supportive, the community environment (association), the influence of electronic media gadgets. Furthermore, for the implications of the strategy of Islamic religious education teachers in fostering the noble character of students, namely in habituation activities, students carry out the dhuhr prayer in congregation in a disciplined manner without the need for instructions from the teacher (State et al., 2021).

The formation of commendable character can guarantee positive youth development. Aspects of religious education by parents, parental linkages, and peer linkages need to be emphasized in the development of Muslim youth because implementing the appreciation of Islamic morality in every young person will shape the youth into human beings who are respected highly praised by the community. This young generation will shape the country's future and shape the glory of a nation's civilization. Youth is the most important asset and will inherit the country's future leaders. This group is the largest group of people in Malaysia, and the majority are young Muslims. Forming young people with noble character requires a balance between formal and informal education. The informal learning process passed with the community, especially parents and peers, should not be taken lightly; it needs to be given serious attention because the period spent with parents and peers is longer than the time spent in formal education. Building young morals to become brilliant and balanced human beings in terms of intellect and spirituality is a lifelong educational process. It needs to be emphasized in line with the development and progress of the country. A positive youth is a youth who has a commendable character. The appreciation of Islamic morals needs to start from a young person and develop to form a society with noble character, and then form glorious nationhood, as stated by the Prophet Muhammad. especially parents and peers, should not be taken lightly; in fact, it needs to be given serious attention because the period spent with parents and peers is longer than the time spent in formal education. Building young morals to become brilliant and balanced human beings in terms of intellect and spirituality is a lifelong educational process. It needs to be emphasized in line with the development and progress of the country. A positive youth is a youth who has a commendable character. The appreciation of Islamic morals needs to start from a young person and develop to form a society with noble character, and then form glorious nationhood, as stated by the Prophet Muhammad. Especially parents and peers should not be taken lightly; it needs to be given serious attention because the period spent with parents and peers is longer than the time spent in formal education. Building young morals to become brilliant and balanced human beings in terms of intellect and spirituality is a lifelong educational process. It needs to be emphasized in line with the development and progress of the country. A positive youth is a youth who has a commendable character. The appreciation of Islamic morals needs to start from a young person and develop to form a society with noble character, and then form glorious 
nationhood, as stated by the Prophet Muhammad. Serious attention needs to be given because the period spent with parents and peers is longer than that spent in formal education. Building young morals to become brilliant and balanced human beings in terms of intellect and spirituality is a lifelong educational process. It needs to be emphasized in line with the development and progress of the country. A positive youth is a youth who has a commendable character. The appreciation of Islamic morals needs to start from a young person and develop to form a society with noble character, and then form glorious nationhood, as stated by the Prophet Muhammad. Serious attention needs to be given because the period spent with parents and peers is longer than that spent in formal education. Building young morals to become brilliant and balanced human beings in terms of intellect and spirituality is a lifelong educational process. It needs to be emphasized in line with the development and progress of the country. A positive youth is a youth who has a commendable character. The appreciation of Islamic morals needs to start from a young person and develop to form a society with noble character, and then form glorious nationhood, as stated by the Prophet Muhammad. Building young morals to become brilliant and balanced human beings in terms of intellect and spirituality is a lifelong educational process. It needs to be emphasized in line with the development and progress of the country. A positive youth is a youth who has a commendable character. The appreciation of Islamic morals needs to start from a young person and develop to form a society with noble character, and then form glorious nationhood, as stated by the Prophet Muhammad. Building young morals to become brilliant and balanced human beings in terms of intellect and spirituality is a lifelong educational process. It needs to be emphasized in line with the development and progress of the country. A positive youth is a youth who has a commendable character. The appreciation of Islamic morals needs to start from a young person and develop to form a society with noble character and form glorious nationhood, as stated by the Prophet Muhammad (Tan \& Abiddin, 2016).

In 1982, the Prime Minister of Malaysia, Mahathir Muhammad, decided to instill Islamic values in the government. Thus the role of Islam is increasingly essential. A year later, in 1983, the Ministry of Education stated that moral values would be taught to non-Muslim students, while religious knowledge would be taught to Muslim students (Olive, 2011). Understanding Islamic teachings, including morals among respondents, is at the highest stage for each aspect studied.

The study results found that the stage of practicing Islamic teachings, including morals, was also high. However, a small percentage of respondents do not practice what they understand, especially matters relating to morality. Therefore, the implications of this study show that emphasizing aspects of the practice of Islamic teachings are very important so that students become Muslims who practice good morals in daily life based on the Koran and as- 
Sunnah (Shafie \& Othman, 2017). There is a need to contribute to the literature by developing a Muslim character test that can be used to measure morality at the student level.

The development of valid and reliable tests requires special knowledge. There is literature on test construction. When a teacher constructs a test, it is a test made by a poorly prepared teacher. Then when an expert constructs a valid and reliable test, it is called a standardized test. However, a teacher can make a test if appropriately guided. The problem of teachers in preparing poor tests is a significant problem in education that requires special attention. However, teachers should consult with experts before using the test (Osadebe, 2012). It is even suggested for experts to create tests for teachers to use. Thus, non-standard and standard tests can be produced by experts.

The construction and standardization of tests is a particular area for those with a background (Nunnally, 1981; Osadebe, 2001). Researchers who are experts in test construction and standardization decided to build a valid and reliable Economic Achievement Test for teachers as an area of need. Tests will only be given when needed to avoid abuse. It should be used in assessing student achievement after teaching and learning Economics, especially when content areas have been covered. Therefore, to create a valid and reliable achievement test for use by teachers and others, especially when the content areas of the high school-level Economics curriculum have been covered. The procedure used in constructing the test is similar to that of Gronlund (1985), Nunnally (1981), Okonkwo (1995), Osadebe $(2012 ; 2014)$.

The cognitive tests developed in this study are included in the reliable category where (a) shows 0.938 , indicating that this moral science knowledge test kit is adequate to collect data.

\section{CONCLUSION}

Based on these findings, this achievement test is an objective test because we assess students objectively. Especially the multiple-choice questions. For cognitive tests, it is pretty challenging to make questions. Because the compilers of cognitive tests in the form of multiplechoice questions must consider that the wrong answer choices must be able to deceive less educated students, in compiling answers, test authors must use their ability to make the wrong answers the same as the correct answers, not too much difference so that it is easy for respondents to guess.

\section{REFERENCES}

Abu-Raiya, H. (2015). Working with Muslim religious clients: A dynamic, quranic-based model of psychotherapy. Spirituality in Clinical Practice, 2(2), 120-133. https://doi.org/10.1037/scp0000068

Adams, A. (201 1). The Need for Character Education. International Journal of Social Sciences 
and Humanity Studies, 3(2), 23-32.

Ahmad, S., Sultana, N. \& Jamil, S. (2020). Considerations for Constructing and Validating Biology Achievement Test at Secondary Level. US-China Education Review B, 10 (1), 1325. https://doi.org/10.17265/2161-6248/2020.01.002

Ano, G. G., Pargament, K. I., Wong, S., \& Pomerleau, J. (2017). From vice to virtue: Evaluating a manualized intervention for moral-spiritual struggles. Spirituality in Clinical Practice, 4 (2), 129-144. https://doi.org/10.1037/scp0000128

Azwar, S. (2012). Penyusunan Skala Psikologi (Edisi 2). Pustaka Pelajar.

Azwar, S. (2017). Dasar-Dasar Psikometri. Pustaka Pelajar.

Balta, N., \& Eryllmaz, A. (2020). Development of Modern Physics Achievement Test: Validity and Reliability Study. The European Educational Researcher, 3(1), 29-38. https://doi.org/10.31757/ever.313

Chang, L. H. (2010). An appraisal on the implementation of moral education for schools in Malaysia. Proceedings of The 4th International Conference on Teacher Education, November, 3-12.

Depdikbud. (2005). Panduan Analisis Butir Soal. Depdikbud.

Harcourt, P. (2019). Construction And Validation Of Chemistry Achievement Test For Senior Secondary Schools In Bayelsa State. 7(2), 106-110.

Hidayat, W. Ahmad, J.B. \& Hamzah, M.I.B. (2018). Nilai Keutamaan Pengetahuan Dan Kebijaksanaan Dalam Konteks Pendidikan Karakter Bangsa. Jurnal Penelitian Dan Evaluasi Pendidikan, 22 (1), 83-91.

Lawhon, D. (1976). Instructional development for training teachers of exceptional children: A sourcebook. Journal of School Psychology, 14(1), 75. https://doi.org/10.1016/00224405(76)90066-2

Lekwa, A. J., Reddy, L. A., Dudek, C. M., \& Hua, A. N. (2018). Assessment of Teaching to Predict Gains in Student Achievement in Urban Schools. School Psychology Quarterly, 34 (3), $271-$ 280. https://doi.org/10.1037/spq0000293

Marzuki. (2015). Pendidikan Karakter Islam. AMZAH.

Montiel, C. J., de la Paz, E., \& Cerafica, Z. I. (2019). (De)humanization and trust in an asymmetric Muslim-Christian conflict: Heroes, Kafirs, and Satanas. Peace and Conflict, 25 (4), 300-31 1. https://doi.org/10.1037/pac0000418

Negeri, S. M. A., Negeri, S. M. A., Negeri, S. M. A., Negeri, S. M. A., Negeri, S. M. A., Negeri, S. M. A., Negeri, S. M. A., \& Negeri, S. M. A. (2021). STRATEGI GURU PENDIDIKAN AGAMA ISLAM DALAM MEMBINA AKHLAK MULIA SISWA SMAN 1 BANDUNG Asep Kusno Suseno Universitas Islam Nusantara Diterima: Abstrak Direvisi : Disetujui : Kata Kunci: Strategi, Guru PAl, Pembinaan Akhlak Mulia Abstract Strategi Guru P. 1, 705-714.

Osadebe, P. U. (2014). Construction of Economics Achievement Test for Assessment of Students. World Journal of Education, 4(2), 58-64. https://doi.org/10.5430/wje.v4n2p58 
Santrock, J. W. (2011). Psikologi Pendidikan (Edisi 2). Kencana Media Grup.

Scherrer, V., Preckel, F., Schmidt, I., \& Elliot, A. J. (2020). Development of achievement goals and their relation to academic interest and achievement in adolescence: A review of the literature and two longitudinal studies. Developmental Psychology, 56 (4), 795-814. https://doi.org/10.1037/dev0000898

Shafie, M. K., \& Othman, M. K. B. H. (2017). Kefahaman Dan Pengamalan Akhlak Dalam Kalangan Pelajar Politeknik Sultan Abdul Halim Mu'Adzam Shah. Proceedings of the ICECRS, 1 (1), 663-676. https://doi.org/10.21070/picecrs.v1i1.540

Sugiyono. (2014). Metode Penelitian Kuantitatif, Kualitatif, dan Kombinasi (Mixed Methods). Alfabeta.

Sukiman. (2012). Pengembangan Sistem Evaluasi. Insan Madani.

Tan, R., \& Abiddin, N. Z. (2016). Tinjauan Permasalahan Akhlak Belia di Institusi Pengajian Tinggi. Mimbar Pendidikan, 1 (2), 161. https://doi.org/10.17509/mimbardik.v1i2.3939

Thiagarajan, S., Semmel, D. S. dan Semmel, M. I. (1974). Instructional Development for Training Teachers of Exceptional Children. The University of Minnesota.

Ultra, P., Hawi, A., \& Suryana, E. (2020). Strategi Guru Pendidikan Agama Islam dalam Pembinaan Akhlak Siswa di Sekolah Menengah Kejuruan (SMK) Kota Palembang. Muaddib: Islamic Education Journal, 7(1), 65-72.

Vargas, L., \& González-Torres, M. C. (2009). The revitalization of character education in today's educational psychology arena: Contributions from the sciences of Prevention and positive psychology. Electronic Journal of Research in Educational Psychology, 7(19), 1379-1418.

Wagner, L., \& Ruch, W. (2015). Good character at school: Positive classroom behavior mediates the link between character strengths and school achievement. Frontiers in Psychology, 6(MAY), 1-13. https://doi.org/10.3389/fpsyg.2015.00610

Weber, M., \& Ruch, W. (2012). The role of a good character in 12-year-old school children: Do character strengths matter in the classroom? Child Indicators Research, 5(2), 317-334. https://doi.org/10.1007/s12187-011-9128-0

Zaitun. (2011). Pendidikan Islam Di Malaysia. Al-Fikra: Jurnal IImiah Keislaman, Vol. 10, No. 1, Januari-Juni $2011,10(1)$. 